UDC 821.161.2

DOI https://doi.org/10.24919/2308-4863/38-2-19

Olesia MINENKO,

orcid.org/0000-0001-8981-3726

Candidate of Philological Sciences, Associate Professor, Associate Professor at the Department of Foreign Languages Cherkasy Institute of Fire Safety named after Chornobyl Heroes of National University of Civil Defense of Ukraine (Cherkasy,Ukraine) alesyaminenko@ukr.net

Yana SNISARENKO, orcid.org/0000-0001-5438-6170

Candidate of Philological Sciences, Associate Professor, Associate Professor at the Department of Translation, Applied and General Linguistics Volodymyr Vynnychenko Central Ukrainian State Pedagogical University (Kropyvnytskyi,Ukraine) yanasnis@gmail.com

Oksana SPIRKINA, orcid.org/0000-0001-7932-0127

Candidate of Historical Sciences, Associate Professor, Associate Professor at the Department of Foreign Languages Cherkasy Institute of Fire Safety named after Chornobyl Heroes of National University of Civil Defense of Ukraine (Cherkasy, Ukraine) ksenyasp@gmail.com

\title{
FEATURES OF LITERARY TRANSLATION AND INTERPRETATION IN SCIENTIFIC DISCOURSE
}

The issues of literary translation and interpretation are investigated in the article. The analysis of the views of the researchers T. Denisova, L. Vygotsky, $R$. Ingarden on the research topic is given. The characteristic features of literary translation are highlighted and described. Based on the study, it is established that the reception of a work of art is determined on the basis of the work of understanding the original text, as a result of the dialogue between the text and the translator; as a manifestation of the hidden meaning that passes through the translational consciousness.

Each new translation of the work acquires relative independence; it carries something uniquely individual, created by the translator - the writer. The creative personality of the translator inevitably influences the translated work, which is perceived by the reader through the prism of his personality. When translating a literary work belonging to a certain national culture and created by appropriate means of linguistic and stylistic systems, it is possible to reflect the phenomena inherent in the national artistic consciousness.

The aim of the article is to investigate the characteristic features of literary translation and interpretation in scientific discourse.

The article reveals the meaning of the concept of "reception", which is dynamic, because the reception continues until new translations, new translation studies. Though, each work of art is a holistic ideological and creative structure in which the individual parts interact organically and form an inseparable unity, all elements of this structure are open to the reader, and in the process of cognition are realized differently in his mind.

In the course of the study, it was revealed that the specific process of perception of a work of art in all people has an individual character, differs both in the level of emotional sensitivity and in the nature of ideas that arise in the process of perception of the same work of art. This depends on many factors: a person's emotional experience, interests, aesthetic taste, the type of perception inherent in a person, the level of emotional development of a person, the physical and psychological state at the time of perception, the conditions under which this process takes place, the attitude to perception, the ability of a person to fully perceive works of art.

Key words: translation, reception, interpretation, author, work, translator, reader, discourse.

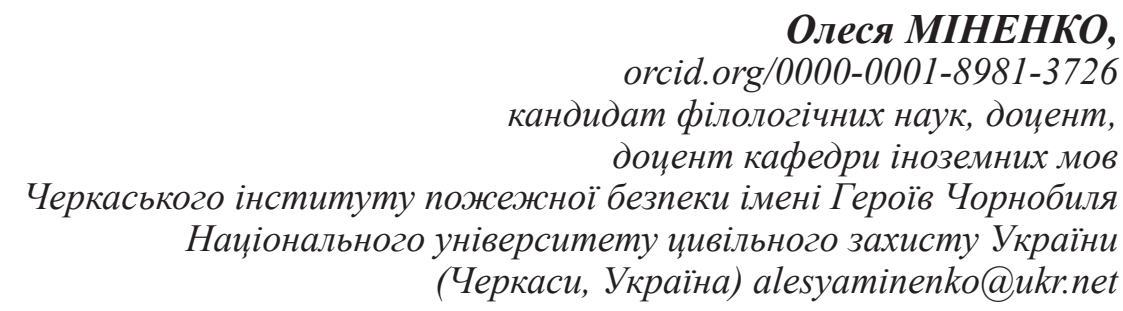




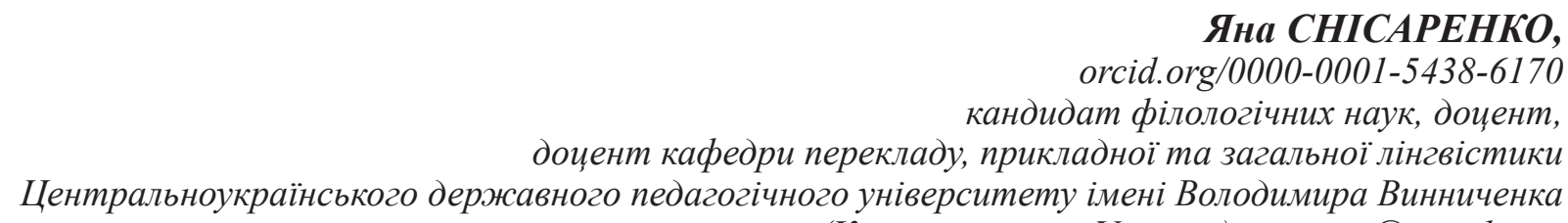

(Кропивницький, Украӥна) yanasnis@gmail.com

Оксана СПІРКІНА, orcid.org/0000-0001-7932-0127 кандидат історичних наук, дочент, доиент кафедри іноземних мов Черкаського інституту пожежної безпеки імені Героїв Чорнобиля Національного університету ичивільного захисту України (Черкаси, Украӥна) ksenyasp@gmail.com

\section{ОСОБЛИВОСТІ ХУДОЖНЬОГО ПЕРЕКЛАДУ ТА ІНТЕРПРЕТАЦЇ̈ В НАУКОВОМУ ДИСКУРСІ}

У статті розкрито питання художнього перекладу та інтерпретаиії. Наведено аналіз поглядів дослідників Т. Денисової, Л. Виготського, Р. Інгардена з досліджуваної теми. Виділено та описано характерні особливості художнього перекладу. На основі дослідження встановлено, щзо рецепція художнього твору визначається на основі праці розуміння первинного тексту, тобто в результаті появи діалогу між текстом і перекладачем; як прояв прихованого смислу, щяо проходить крізь перекладацьку свідомість. Кожний новий переклад твору набуває відносної самостійності, він несе в собі щзось неповторно індивідуальне, створене перекладачем - письменником. Творча особа перекладача неминуче впливає на перекладений твір, який сприймається читачем уже крізь призму його особи. Під час перекладу літературного твору, щуо належсть певній національній культурі та створений відповідними засобами мовної і стилістичної систем, можна зображувати явища, властиві національній художній свідомості.

Метою статті є дослідити характерні особливості художнього перекладу та інтерпретації в науковому дискурсі.

У науковій розвідиі розкрито зміст поняття «рецепџія», щзо є динамічним, оскільки рецепція триває доти, доки з'являються нові переклади, нові перекладознавчі дослідження. Оскільки кожний художній твір є иілісною ідейно-творчою структурою, у якій окремі частини органічно взаємодіють і становлять нерозривну єдність, усі елементи цієї структури є відкритими для читача і в прочесі пізнання по-різному реалізуються в його свідомості.

У процесі дослідження було виявлено, щзо конкретний проиес сприйняття витвору мистецттва у всіх людей має індивідуальний характер, відрізняється як за рівнем емочійної сприйнятливості, так $і$ за характером уявлень, щзо виникають у проиесі сприйняття одного й того ж твору мистеитва. Це залежить від багатьох факторів: емоиійного досвіду людини, інтересів, естетичного смаку, властивого людині типу сприйняття, рівню емоційного розвитку людини, фізичного й психологічного стану в момент сприйняття, умов, за яких протікає цеей процес, установки на сприйняття, здатності людини до повноцінного сприйняття творів мистецтвва.

Ключові слова: переклад, рецепція, інтерпретачія, автор, твір, перекладач, читач, дискурс.

Introduction. A literary text like any other work of art is aimed at perception. The recipient's perception of the text is a powerful psychological process. For some time, psychologists have been studying the problem of perception. They made significant progress in the experimental study of sensory processes, which made it possible to study artistic perception much better. But for a broader analysis of reception, collaboration with literary critics was important. The analysis of perception from the standpoint of psychology did not open up the possibility of studying the aesthetic impact on the recipient, did not reveal the evolution of perception, and so on. Thus, psychologists were forced to intervene in the field of literary studies and turn to the concepts and categories of literature and aesthetics.

Purpose. The main purpose of the article is to investigate the characteristic features of literary translation and interpretation in scientific discourse.

Research methods. In the course of the scientific research, the methods of analysis adopted in theoretical literature, including comparative analysis, were used. The methodological basis of the research consists of scientific works on literary theory. The research methodology is based on the use of general scientific methods (analysis, synthesis and generalization), methods of empirical research and special methods (deduction and induction).

Results and discussion. The problem of reception of literary texts is not only related to the expansion of the paradigms of high artistic value of recipient literature. It is also important to take into account how reception takes place, in what form texts of other cultures enter the new artistic and national 
space, and at what time this intercultural dialogue takes place. That is why it is important to take into account the peculiarities of the cultural and historical consciousness of the period in which the reception takes place. As T. Denysova notes, the study of such categories as "canon" and "reception" helps in studying the history of the development of genres and styles of certain national literature, which is the main task of literary translation. "The history of genres, directions and schools can be structured according to the principles of genesis, reception, poetology, comparativistics, narrativistics and the history of ideas" (Denysova, 2002: 6). Thus, the reception of translation will be perceived ambiguously by different generations, which in turn gives an impetus to the study of the development of the literature of that time and culture of the population of that period.

Over the past ten years, a number of outstanding works have appeared in the Ukrainian literary studies, which aim primarily to reveal the creative thinking of a certain cultural and historical era through the comparison of one national literature with another one, or to show how a model (at the genological and stylistic levels) of national literature is formed through the dialogue of one cultural and historical consciousness with another one. This topic was at the center of monographs and studies by V. Aheieva, S. Andrusiv, A. Bila, V. Budnyi, T. Hundorova, T. Denysova, D. Zatonskyi, M. Ilnytskyi, I. Limborskyi, Yu. Mykytenko, R. Movchan, V. Morenetz, D. Nalyvaiko, M. Novikova, A. Niamtsu, S. Pavlychko, O. Pakhlovska, L. Plyushch, Ya. Polishchuk, O. Pronkevych, T. Riazantseva and others. The research of these scientists has to reach a new level of understanding of literary thought, involving in its field vectors of development of various national literary systems and philosophical and aesthetic traditions. At the same time, it is worth noting that over the past five years, the problem of reception has been updated in the Ukrainian literary studies, the impetus for which was the studios of S. Pavlychko, T. Denysova, D. Nalyvaiko, T. Mykhed and T. Hundorova. After all, there are quite a few studies in which the analysis of translations is considered from the point of view not so much from the linguistic side as from the comparative one, which is a transition link to generalizations in the plane of aesthetics. Translation is not only a form of conveying the text of another culture to its own one, but also an expression of the cognitive (mental) features of the culture of a certain historical time. «Literature, being a verbal art, is connected in a special way with the cognitive-mental sphere and is the only one in the ensemble of arts that is its direct artistic expression»", D. Nalyvaiko noted (Nalyvaiko, 2006: 21).
A significant contribution to solving the problem of artistic perception (in particular, a literary work) was made by L. Vyhotskyi in the book "Psychology of Art". He speaks about the relationship of perception with the feelings and imagination of a person and the primary importance of the latter as the basis of aesthetic reaction: "The problem of perception is one of the most important problems of the psychology of art, but it is not a central problem. In the art, the act of sensory perception, of course, only begins, but does not end the reaction, and therefore the psychology of art has to begin not with the section that usually deals with the elementary aesthetic experiences, but with the other two problems - feelings and imagination" (Vyhotskyi, 1997: 237). Based on the research of L. Vyhotskyi, we can confidently say that for a full reception of fiction or a work of art, the author needs to use mechanisms that excite our imagination and feelings, although some researchers believe that a deeper individual perception of the work can be achieved using other methods.

Thus, R. Ingarden defined the development of receptive aesthetics in a structural mode, contrasted the artifact and concretization, within which the reader fills in the points of uncertainty that belong to the artifact at different levels. The researcher, in contrast to the banal reader, should reconstruct the process of concretization itself in order to identify the correlation between the artifact and the concretization made in the act of reading (Ingarden, 1962: 372). According to R. Ingarden, for a deeper perception of fiction, the author leaves points of uncertainty, which allows the reader to fill them independently, thereby more deeply linking the plot of the work with their own thoughts and experiences. Using this mechanism, the author should clearly outline the places of concretization in his work, so that the reader cannot move away from the general storyline and fully comprehend the deep meaning of the fiction.

At the same time, U. Eco has the only possible actual data of the artifact for the recipient, and therefore it is fundamentally impossible to distinguish a pure artifact and a pure concretization, since any reconstruction meets with concretization in the researcher's own head, because he is primarily a reader. This state of affairs, or, in other words, the hermeneutical circle in which normative aesthetics is localized, forces its adherents to look for criteria for "true" interpretation as opposed to "excessive" one (Eco, 2002: 549). When studying a fiction for compliance with the artifact and the place of concretization in it, it is not always possible to fully achieve the goal. Even the author perceives his work differently after repeated reading under the influence of new emotions, moods, and life situations. 
In the process of artistic perception, M. Bakhtin identifies three stages that are simultaneous and indivisible during live reading; the scientist insists on their semantic differentiation. The first stage of reading activity - the "getting in" stage - is characterized by the fact that the reader learns the hero's living space as his own. The reader seems to merge with the hero, feels, experiences what he does. The reader becomes a reader-hero: he sees the world in which events take place, becomes a participant in them, getting used to the hero, identifying his thoughts with his own. The "getting in" stage is not able to abstract the reader from the real world. As to M. Bakhtin, the completeness of the reader's inner fusion with the hero is not the goal of his aesthetic activity. Aesthetic activity begins at the next stage when the most important aesthetic event occurs - the meeting of the author and reader. M. Bakhtin calls the author's activity "the activity which opens up" and the activity of the reader - "the activity of the one who understands". The meeting between the author and the reader largely depends on the ability of the former to express himself, convey his own attitude to the event, as well as on the ability of the reader to understand the author, that is, to unravel the form and comprehend. According to M. Bakhtin, the reader, to a certain extent, becomes the "creator of a form", because the form is an expression of the active value attitude of the author-creator and perceiver to the content and gives it meaning - this is the stage of completing the perception of a literary text. The process of perception of the phenomenon of verbal art is embodied in the fact that the literary work should not only be "heard, understood", but also have "an answer" (the idea of dialogicism). This concept of communication between the writer and the reader is based on the value attitude to art and is a unity of "merging" and "non-merging" of their positions (Bakhtin, 1975: 276). The problem of true (author's) perception of a fiction is particularly acute for the translator, who, along with his own interpretation of events, must follow the author's plan.

In order to track how much the translation is congenial to the original, we consider it is necessary to determine the most important coordinates that the translator must adhere to when working on a fiction. First of all, this concerns the problem of understanding and reader perception. Since the reader (translator) does not have a direct knowledge of what the initiator of speech has, he must try to understand much of what remains incomprehensible to him, except in the case when he, reflecting on himself, becomes his own reader. The author is, firstly, the creator of a fiction, a real person with a certain fate, biography, complex of individual features, secondly, it is the image of the author localized in the fiction, and thirdly, it is the artist-creator, immanent of the work. In the process of working, the translator often has to overcome some personal fears; sometimes they can take the form of hatred for a foreign language, which is perceived as a threat to the language identity of the translator himself. However, the work on translation, according to P. Riker, has its own deep sadness, because the "completed" translation is unattainable and the translator must at some point abandon the realization of his ideal (Riker, 2007: 288).

The presence of the author in the work is the key in the artistic activity. Author's specificity appears as a multi-faceted, individual and outstanding feature, which is perceived as the embodiment of the author's spirit in the artistic creativity. The main feature of understanding is the similarity and difference between the author of the work and the reader (F. Schleiermacher, V. Diltey, G. Gadamer). According to these principles of "alienness" and "kinship", speech is modified and developed through the influence of human individuality (the author as the initiator of speech) on it, on the one hand, and on the other hand - the author himself depends on the language when creating a fiction. Supporting Humboldt's position on a language as "a continuous process of creativity and creation through individual speech acts", F. Schleiermacher wrote: "Just as any speech has a twofold relation - to the totality of a language and to the aggregate thinking of its initiator, so any understanding consists of two points: the understanding of speech as introduced from a language and as a fact of concrete thinking". Thus, the art of understanding consists in penetrating, on the one hand, into the "spirit of speech", and on the other hand - into the "originality of the writer" (F. Schleiermacher, 2004: 129).

Translation of fiction is directly related to comparative literary studies, which can play a priority or marginal role depending on the aesthetic needs of a certain historical era, artistic guidelines, and the socio-cultural context as a whole. Each literary epoch forms a series of "priority" works for translation and, accordingly, less necessary ones. To a large extent, the processes of determining the importance of the text are influenced by the translator himself. His choice is formed by his own aesthetic tastes and preferences, the general level of education and erudition, and sometimes even a personal attitude to the author of the original, which should be translated. It is quite justified that D. Diuryshyn, Yu. Lotman, M. Strikha, P. Toper and others propose to distinguish between objective and subjective factors that determine the 
perception of an original work by a translator. In particular, according to the latter, the translator "cannot abstract from the subjective perception of the work translated by him, and his creative personality will inevitably, against his will, affect the translation. If objective prerequisites are determined primarily by the ratio of the nature of the work and modern norms in the literature that perceives it, then subjective ones are expressed in the ratio of the artistic taste of the translator and the ideological and artistic features of the original" (Toper, 2000: 127).

The first thing that connects reception with the sphere of literary translation is language, which serves to reveal the potential of perception of the work, as M. Lanovyk rightly notes (Lanovyk, 2006: 249). But no literary work allows for unambiguous understanding. Incomprehensible lexical units provide a certain freedom of the reader in terms of reception of the work, and therefore it is reliable that the recipient will add their own arguments to the perceived semantic spectrum, which the author did not have in mind. In his research, W. Humboldt tried to show the positive impact of translation on the development of the native language. "The meeting" of languages in the translation process, which in turn is a comparison of language units, that is, their "fitting" to each other, leading to interpenetration, and as a result to the enrichment of the translation language: "translation serves to expand the semantic capabilities and expressiveness of the native language", W. Humboldt noted (Humboldt, 1984: 87).

The realization that a literary work manifests itself in a complex trinity of the author, text, and reader, and the analysis of multi-level connections within such an attitude allow modern comparativistics to explore new aspects of the problem of perception at the junction with aesthetics, psychology, philosophy, sociology, and other sciences. To a certain extent, reception research is a purely comparative project, since it involves an appeal to two cultural and ideological codes: on the one hand, we study how "another" national mentality, realized through the artistic space, affects "its" national system, how the traditional reading of a certain work or a set of works, the author or traditional images, etc. is repelled in the new artistic system; on the other hand, the study of reception also pushes us to study the laws of development of the national artistic system, since all influences leave a certain ideological and aesthetic mark on the "body" of another artistic system.

The question of the nature of artistic perception of a literary work was studied by aestheticians, artists, art historians, and translation specialists. All of them noted the presence of an experience of aesthetic pleasure in the process of artistic perception. What is the basis of this? Researchers of artistic perception have given different answers to this question. The reception of a fiction is not only reduced to imaginative thinking, but it is based on emotional processes. First of all, it is an artistic emotion - empathy for an artistic image, which causes the emergence of another special emotion - empathy for yourself. These two emotions begin to interact in two different ways. The first method of interaction is that by empathizing with the artistic image (in literature - with artistic empathy for a fictional hero), empathy for oneself returns to its original creation, that is, it affects empathy for the artistic image, enriching it. Therefore, empathizing with the artistic image of the hero, the recipient (author) of the fiction simultaneously empathizes with their disturbing emotions.

Conclusions. To conclude, translation is one of the attempts to form a national artistic system. Thus, attention to the translation of a certain fiction is determined, in particular, by the specifics of the historical period in which the reception of the work takes place, and the peculiarity of the development of genre traditions of national literature of a certain historical time.

That is, in other words, a dialectical process in which the interaction between the work and the recipient occurs through literary communication, because it is through interaction that a continuous exchange between the author, the work and the reader, between the present and past experience of art, is realized. The reader (or better yet, the addressee) perceives a literary work differently: he can simply consume it or, at best, criticize it, admire it or deny it, play with its form, interpret its content, accept recognized interpretations, or try to write a story himself. The process of literary communication is extremely fascinating and original. A reader who deeply perceives the work can feel a spiritual connection with the author, and this, in turn, is a different level of artistic perception of a literary work.

\section{BIBLIOGRAPHY}

1. Бахтин М. М. Вопросы литературы и эстетики. Исследования разных лет. Москва : Худ. литература, 1975. $504 \mathrm{c}$.

2. Выготский Л. С. Психология искусства. Анализ эстетической реакции. Москва : Лабиринт, 1997. 416 с.

3. Гумбольдт В. О. Различие строения человеческих языков и его влиянии на духовное развитие человечества. Избранные труды по языкознанию. Москва : Прогресс, 1984. 400 с. 
4. Денисова Т. Н. Історія американської літератури XX століття. Київ : Довіра, 2002.318 с.

5. Еко У. Надінтерпретація текстів. Слово. Знак. Дискурс. Антологія світової літературно-критичної думки ХХ століття / за ред. М. Зубрицької. 2-ге вид., доп. Львів : Літопис, 2002. С. 549-564.

6. Ингарден Р. Исследования по эстетике. Москва : Изд-во иностранной литературы, 1962. 572 с.

7. Лановик М. Б. Проблеми художнього перекладу як предмет літературознавчої рефлексії : дис. ... д-ра філол. наук : 10.01 .06 - теорія літератури; Тернопільський національний педагогічний ун-т ім. Володимира Гнатюка, Тернопіль, 2006. $410 \mathrm{c}$.

8. Наливайко Д. С. Теорія літератури й компаративістика. Київ : Вид. дім «Києво-Могилянська академія», 2006. $347 \mathrm{c}$.

9. Рикёр П. Парадигма перевода. Лингвистические аспекты теории перевода : хрестоматия. Ереван : Лингва, 2007. $307 \mathrm{c}$.

10. Топер П. М. Перевод в системе сравнительного литературоведения. Москва : Наследие, 2000. 252 с.

11. Шлейермахер Ф. Герменевтика. Санкт-Петербург : Европейский Дом, 2004. 242 с.

\section{REFERENCES}

1. Bahtin, M. M. (1975). Voprosy literatury i estetiki. Isledovania raznyh let. [Questions of literature and aesthetics. Studies of different years]. M.: Khud. literatura [in Russian].

2. Vyhotsky, L. S. (1997). Psihologia iskustva. Analiz esteticheskoy reaktsii [Psychology of art. Analysis of the aesthetic response]. M.: Labirint [in Russian].

3. Humbolt, V. O. (1984). Razlichie stroenia chelovecheskih yazykov i ego vliyanie na duhovnoe razvitie chelovechestva [The difference in the structure of human languages and its influence on the spiritual development of mankind]. Izbrannye trudy po yazykoznaniyu. M.: Progress [in Russian].

4. Denysova, T. N. (2002). Istoria amerukanskoyi literatury XX stolittia [History of American literature of the twentieth century]. K.: Dovira [in Ukrainian].

5. Eco, U. (2002). Nadinterpretatsia tekstiv [Over-interpretation of texts. The word]. Slovo. Znak. Dyskurs. Antologia svitovoyi literaturno-krytychnoyi dumky XX stolittia / za red. M. Zubrytska. 2-he vyd., dop. Lviv : Litopys [in Ukrainian].

6. Ingarden, N. (1962). Isledovania po estetike [Research on aesthetics]. M.: Izd-vo inostranoy literatury [in Russian].

7. Lanovyk, M. B. (2006). Problemy hudojnyogo pereklady yak predmet literaturoznavchoi refleksii [Problems of literary translation as a subject of literary reflection]. (Unpublished Doctoral dissertation.). Ternopilskyi natsionalnyi pedahohichnyi un-t im. Volodymyra Hnatyuka, Ternopil [in Ukrainian].

8. Nalyvayko, D. S. (2006). Teoria literatury $i$ komparatyvistyka [Literary theory and comparative studies]. K.: Vyd. dim "Kyievo-Mohylianska akademia" [in Ukrainian].

9. Riker, P. (2007). Paradigma perevoda [Translation paradigm]. Lingvisticheskie aspekty teorii perevoda. Hrestomatia. Erevan: Lingva [in Russian].

10. Toper, P. M. (2000). Perevod v sisteme sravnitelnogo literaturovedenia [Translation in the system of comparative literature studies]. M.: Nasledie [in Russian].

11. Schleiermacher, F. (2004). Germenevtika [Hermeneutics]. SPb.: Evropeyskiy Dom [in Russian]. 